\section{Clinical implications}

- Chronic constipation is common in elderly people in long stay hospital and nursing home care and regular laxative treatment is often required

- There are few comparative clinical studies of commonly used laxatives

- In this study a senna-fibre combination was more effective than lactulose in long stay elderly patients with constipation

- Both treatments were well tolerated

- The superior efficacy of the senna-fibre combination, without increase in side effects, resulted in considerable cost benefit compared with lactulose.

combination the incidence of adverse effects was no different, both compounds being well tolerated.

The issue of cost effectiveness was addressed in this study. A higher daily dose was needed for an effect with lactulose. There were significant cost savings with the senna-fibre combination over the study period. Extrapolation of these data to the large numbers of long stay elderly people in nursing homes and hospitals who require regular laxatives could result in considerable cost savings. These results would seem to concur with statements on the relative expense and efficacy of lactulose. ${ }^{3412}$

In conclusion, both the senna-fibre combination and lactulose were effective, well tolerated treatments for chronic constipation in long stay elderly patients. Under the study conditions the senna-fibre combination was more effective than lactulose and was a less expensive regimen, a significant advantage in times of clinical and financial audit.

Study participants were Dr A Mehrzad, Mr J Milligan, and
Ms G Johnston of Bishop Auckland General Hospital, Co Durham; Drs P Dalton and N Plant of The Surgery, Kingsmillford, Dudley, West Midlands; Drs P G Flanagan, A Sarkar, and A Moore and Ms M Hetherington of Waveney Hospital, Ballymena, and Masserene Hospital, Antrim, Co Antrim; Dr T R O Beringer of Royal Victoria Hospital, Belfast; Drs J G McConnell and I C Taylor of Ulster Hospital, Dundonald, Northern Ireland.

We thank the medical, nursing, and pharmacy staff in the participating units for their assistance with this study and Galen Limited and Madaus AG for their contribution towards the study.

1 Rouse M, Mahapatra M, Atkinson SM, Prescott P. An open randomised parallel group study of lactulose versus ispaghula in the treatment of chronic constipation in adults. Br f Clin Practice 1991;45:28-30.

2 Primrose WR, Capewell RE, Simpson GR, Smith RG. Prescribing pattern observed in registered nursing homes and long stay geriatric wards. Age Ageing 1987;16:25-8.

3 Laxatives: replacing danthron. Drug and Therapeutics Bulletin 1988;26:53-6.

4 Bateman DN, Smith JM. A policy for laxatives. $B M \mathcal{f}^{1988 ; 297: 1420-1}$

5 Fintelmann V, Haase W. Chronic habitual constipation: double blind trial of laxative of known efficacy. Arztliche Praxis 1977;29:25-6.

6 Sanders JF. Lactulose syrup assessed in a double blind study of elderly constipated patients. F Am Ger Soc 1978;26:236-9.

7 Altman DG. Practical Statistics for Medical Research. London: Chapman Hall, 1991:457.

8 Hills $\mathrm{M}$, Armitage $\mathrm{P}$. The two period crossover clinical trial. $\mathrm{Br} f \mathrm{Clin}$ Pharmacol 1979;8:7-20.

9 Godding EW. Laxatives and the special role of senna. Pharmacology 1988; 36(suppl 1):230-6.

10 Andersson M. Drugs prescribed for elderly patients in nursing homes or under medical home care. Compr Gerontol 1989;3(suppl):8-15.

11 Upton DR, Taylor JK, Holmes GKT, Poston JW. Effects of withdrawal of co-danthramer on use of laxatives in a district general hospital. BMf 1988;297:1446-7.

12 Tedesco FJ, Dipiro JT. Laxative use in constipation. Am $f$ Gastroenterol 1985;80:303-9

13 Connolly P, Hughes IW, Ryan G. Comparison of 'duphalac' and 'irritant' laxatives during and after treatment of chronic constipation: a preliminary study. Curr Med Res Opin 1975;2:620-5.

14 Marlett JA, Li BUK, Patron CJ, Bass P. Comparative laxation of psyllium with and without senna in an ambulatory constipated population. $A m$ Gastroenterol 1987;82:333-7.

15 MacLennan WJ, Poder AFWM A comparison of sodium picosulphate (Laxoberal) with standardised senna (Senokot) in geriatric patients. (Laxoberal) with standardised

16 DeWitte P, Lemli L. The metabolism of anthranoid laxatives. Hepatogastroenterology 1990;37:601-5.

(Accepted 23 fuly 1993)

\title{
Problems in assessing contents of metered dose inhalers
}

\section{J Williams, A C Williams, D G Kruchek}

Heathcot Practice, York House Medical Centre, Woking, GU22 7XL D J Williams, general practitioner

A C Williams, psychologist

\section{St Peter's Hospital,} Chertsey, KT16 0PZ D G Kruchek, anaesthetics registrar

\section{Correspondence to:}

Dr Williams.

BMF 1993;307:771-2
Treatment of asthma with $\beta$ agonists delivered via metered dose aerosol inhalers has been associated with excess mortality from asthma. ${ }^{1}$ The canisters of these inhalers are opaque, and patients cannot see how much medication remains in a canister. This means that such patients may tend to run out of medication, which could be related to the excess mortality from asthma. We investigated whether asthmatic patients were able to reliably assess the amount of medication remaining in a metered dose inhaler and whether they ever ran out of medication.

\section{Subjects, methods, and results}

From details of repeat prescriptions we identified all asthmatic patients attending a general practice who were aged 13-22 and used a metered dose inhaler. We notified the patients to come to the surgery with the inhalers they were currently using and any held in reserve. We asked the patients about their use of inhalers and assessed the inhalers by weight. ${ }^{2}$ When an inhaler's canister floats (at its floating weight) it has delivered its licensed number of doses. ${ }^{2}$ Although expellant may be obtained from an inhaler beyond its licensed number of doses ( 36 extra puffs on average for a Ventolin inhaler), there are no published data on the drug content of each puff. As 48 hours is generally required to get a repeat prescription from a general practice, a canister's red weight is when it contains enough expellant for 48 hours' use. $\beta$ Agonists in metered dose inhalers are usually prescribed at two puffs four times daily. The red weight is thus the empty weight (when no further expellant can be obtained) plus the weight of eight doses. We emptied four canisters of each of the metered dose inhalers available (allowing 30 seconds between each expelled dose), measured the appropriate weights, and calculated average weights.

The table shows the answers given by the 51 patients who were interviewed. Only three patients assessed their inhalers by flotation, and when given a nearly empty inhaler none of the patients asked to float the canister before saying that they would continue to use it. Altogether 37 patients sought a replacement when their last inhaler was almost or completely empty, and 36 subjects occasionally or frequently ran out of inhalant (33 of whom had consequently become wheezy or very wheezy). Of the 81 inhalers in current use that were assessed, 21 were at their floating weight and 12 were at their red weight. For five patients both their inhaler for prophylaxis and their inhaler for symptomatic relief were at their floating weights, and for three patients both inhalers were at their red weights. Nineteen patients had no inhaler in reserve. 
Answers given by 51 asthmatic patients to questions about their use of metered dose inhalers

\begin{tabular}{|c|c|c|}
\hline Question & Answer & $\begin{array}{l}\text { No of } \\
\text { subjects }\end{array}$ \\
\hline When do you stop using your inhaler? & $\left\{\begin{array}{l}\text { When nothing comes out of inhaler } \\
\text { When inhaler floats }\end{array}\right.$ & $\begin{array}{r}48 \\
3\end{array}$ \\
\hline $\begin{array}{l}\text { When do you ask for a repeat prescription } \\
\text { of your inhaler? }\end{array}$ & $\left\{\begin{array}{l}\text { When inhaler completely empty } \\
\text { When inhaler nearly empty } \\
\text { When reserve inhaler started }\end{array}\right.$ & $\begin{array}{r}9 \\
28 \\
14\end{array}$ \\
\hline $\begin{array}{l}\text { Have you ever found yourself without an inhaler? } \\
\text { If so, what were the consequences? }\end{array}$ & $\left\{\begin{array}{l}\text { Never without inhaler } \\
\text { No consequences when without inhaler } \\
\text { Became wheezy when without inhaler } \\
\text { Became very wheezy when without inhaler }\end{array}\right.$ & $\begin{array}{r}15 \\
3 \\
25 \\
8\end{array}$ \\
\hline Do you always have inhalers in reserve? & $\left\{\begin{array}{l}\text { Always } \\
\text { Usually } \\
\text { Often no }\end{array}\right.$ & $\begin{array}{l}10 \\
28 \\
13\end{array}$ \\
\hline Would you carry on using this inhaler?* & $\left\{\begin{array}{l}\text { Yes } \\
\text { No }\end{array}\right.$ & $\begin{array}{r}51 \\
0\end{array}$ \\
\hline
\end{tabular}

^Patient handed a salbutamol inhaler that was nearly empty.

\section{Comment}

Nearly all the patients in the study continued to use their inhalers after the canisters had delivered their licensed number of doses. More than half of the patients had run out of medication at some time and had consequently become wheezy. Regular inhalation of $\beta$ agonists desensitises the $\beta$ receptors of the airways, and withdrawal of the medication (or running out of it) may provoke rebound bronchospasm after 16 hours. ${ }^{3}$ The use of one canister of a salbutamol metered dose inhaler (Ventolin) a month is associated with a mortality odds ratio of $2 \cdot 4$, and greater use of the inhaler substantially increases the odds ratio. ${ }^{4}$ This may be because greater use of such an inhaler increases airway desensitisation and increases the chance of running out of medication, increasing the probability of rebound bronchospasm.

Manufacturers of metered dose inhalers are aware of this flaw, and Glaxo stated in a patent for a counter mechanism for inhalers: "the patient cannot determine the amount of medicament in the aerosol container.... This could mean that the patient, possibly suffering from severe bronchospasm and needing a dose of medicament, will find that the aerosol container will not dispense a dose because its contents have already been exhausted."s

We conclude that aerosol metered dose inhalers give insufficient information about the drug remaining in the inhaler and are therefore unsafe. A counter mechanism would rectify the problem.

1 Pearce N, Crane C, Burgess R, Jackson R, Beasley R. Beta agonists and asthma mortality: deja vu. Clin Exp Allergy 1991;21:401-10.

2 Buchanan N. Childhood asthma: what it is and what you can do. London: Piatkus, 1987:73.

3 Vathenen AS, Knox AJ, Higgins BG, Britton JR, Tattersfield AE. Rebound increase in bronchial responsiveness after treatment with inhaled terbutaline. Lancet 1988;i:554-8.

4 Spitzer WO, Suissa S, Ernst P, Horwitz RI, Habrick B, Cockcroft D, et al. The use of $\beta$-agonists and the risk of death and near death from asthma. $N$ Engl f Med 1992;326:501-6.

5 Rand PK, Osterweil CA, Newell RE, inventors. Glaxo Group, assignee. Indicating Device. US patent 4,817,822. 1989 Apr 4.

(Accepted 24 fune 1993)

\section{Smoking and periductal mastitis}

\section{N J Bundred, M S Dover, Nedra Aluwihare, E B Faragher, J M Morrison}

Departments of Surgery and Histopathology, Selly Oak Hospital, Birmingham B29 6JD

N J Bundred, senior lecturer in surgery

MS Dover, registrar in surgery

Nedra Aluwihare, registrar in histopathology

J M Morrison, consultant surgeon

\section{Department of Medical Statistics, University Hospital of South Manchester, Manchester M20 8LR E B Faragher, medical statistician}

\section{Correspondence to:}

Mr N J Bundred, University Hospital of South

Manchester, Manchester M20 8LR.

BMF 1993;307:772-3
Periductal mastitis and duct ectasia are well recognised, ${ }^{12}$ presenting either with acute inflammation of the breast or with chronic breast symptoms such as nipple discharge. The acute inflammatory changes seen in younger women are probably due to periductal inflammation (periductal mastitis) without duct dilatation whereas the chronic symptoms seen in older women are probably due to duct dilatation (duct ectasia) with minimal inflammation. As recurrent breast abscesses are commoner in smokers, we investigated the association between smoking and either periductal mastitis or duct ectasia in patients with a histological diagnosis.

\section{Patients, methods, and results}

Between 1981 and 1990, 71 women were identified with a histological diagnosis of periductal mastitis or duct ectasia (cases). Their clinical presentation, use of oral contraceptives, and smoking habits were recorded. They were designated as non-smokers, light smokers (1-10 cigarettes/day), or heavy smokers (11-40 cigarettes/day).

Two age matched controls were selected for each case from women who underwent surgery for a benign non-breast condition during the same year as the cases (varicose vein removal or cholecystectomy (49), gynaecological procedure (27), otorhinolaryngological procedure (23), skin biopsy (33), and dental procedure (10)). Smoking habits were available for all women but details of oral contraceptive use were unobtainable in 32 controls.

The histopathological specimens from all cases were reviewed, and the degree of periductal inflammation and duct dilatation was graded using a previously described method. ${ }^{2}$ Analysis was based on $\chi^{2}$ and Student's $t$ tests, with analysis of variance and conditional logistic regression.

The mean age of both cases and controls was 43.3 years (range 19-80). The 48 cases with acute symptoms were significantly younger (mean age 40 (SD 13)) than the 23 with chronic disease (47 (14); $t=2 \cdot 06, \mathrm{p}=0.043)$. The cases were significantly more likely to be heavy smokers than the controls $(37(52 \%)$ v $24(17 \%)$ heavy smokers, $11(15 \%) v 22(16 \%)$ light smokers, and $23(33 \%) v 96(67 \%)$ non-smokers, respectively; $\mathrm{p}<0.001$ ). Of all factors considered, smoking emerged as the only significant risk factor for periductal mastitis or duct ectasia, with a relative risk of $6.2(95 \%$ confidence interval 2.9 to $13 \cdot 4)$. Eleven patients had recurrent disease after surgery, of whom 10 were heavy smokers and one a non-smoker.

Smoking and degree of histological inflammation in 71 patients with periductal mastitis or duct ectasia. Values are numbers (percentages) of patients

\begin{tabular}{lrcc}
\hline & \multicolumn{3}{c}{ Histological inflammation } \\
\cline { 2 - 4 } & Acute & Moderate & Chronic \\
\hline Smokers $(n=48)$ & $11(23)$ & $18(37)$ & $19(40)$ \\
Non-smokers $(n=23)$ & $3(11)$ & $3(11)$ & $17(74)$ \\
\hline
\end{tabular}

$\chi^{2}=7 \cdot 5, \mathrm{df}=2, \mathrm{p}=0.023$

Smoking correlated significantly with the degree of periductal inflammation $\left(\chi^{2}=7 \cdot 5, p=0.023\right)$ (table). Duct ectasia was not associated with smoking but was inversely related to the degree of periductal inflammation $(p<0.05)$ and increased with age (mean age of patients with no dilatation 37 (9), with some dilatation 38 (12), and much dilatation 47 (14); $\mathrm{F}(2,67)=5 \cdot 022, \mathrm{p}=0 \cdot 009)$.

\section{Comment}

Histologists have always considered periductal mastitis and duct ectasia to be a single disease. ${ }^{1}$ 